\title{
Activity and Competences of a Music Education Teacher: Expectations of Lithuanian and Foreign Students
}

\author{
Jolanta Lasauskienè
}

Lithuanian University of Educational Sciences, Faculty of Education, Department of Music, 39 Studentų St., LT-08106 Vilnius, Lithuania, jolanta.lasauskiene@leu.lt

\begin{abstract}
The purpose of the present study was to investigate student music teachers' expectations towards their future professional activity and competences of a music teacher. Two groups of students (76 Lithuanian and 64 foreign), who chose studies at Lithuanian University of Educational Sciences, participated in the research. In this article, the results from the qualitative survey carried out in 2017 will be highlighted. The results showed that in music education it is particularly important to combine orientation towards pedagogical activities with orientation towards the spread of the learner's personality. The music students at the University describe their future professional activities as broad and multidimensional ones but they also emphasise the importance of personal values, implementation of general, subject-specific, professional (didactic) competences and continuous improvement. Participation in musical and artistic activities plays a specific role in the spread of professional identity of a music teacher.
\end{abstract}

Keywords: music teacher education, student music teacher, competences, student expectations.

\section{Introduction}

Music education as well as music teacher education raise many issues for discussion. The problem issues related to changes in teacher training have been widely analysed by foreign and Lithuanian educational scientists (Allsup, 2016; Burnard \& Georgii-Hemming, 2016; Gapšytė \& Bankauskienè, 2016; Abramo \& Reynolds, 2015; Zuzevičiūtė \& Bukantaitè, 2012). Much of the debate and research on teacher education internationally 
have consequently centred on how preparation of teachers should be organised (Darling-Hammond, 2017). The music teacher should be a wide profile specialist, sophisticated in music pedagogy, psychology, aesthetics and philosophy of music education, who could meet the most different music needs of school. Such wide-ranging needs of school pose numerous problems in music teacher education and training: what does it mean to be a music teacher in the $21^{\text {st }}$ century? What should qualities and abilities of a music teacher be? What kind of competences do teachers need? How do we educate the next generation of music teachers? What should a university education in music be like?

The main documents regulating the changes in education of teachers in Lithuania emphasise the need to renew and improve teacher's competences (Dèl pedagogų rengimo reglamento..., 2012; Dèl studijų pakopų..., 2016; Dèl pedagogų rengimo modelio..., 2017). Universities are more frequently invited to relate the content of higher education studies with future professional activity and to create study programmes based on competences. To define teacher's competences is a complicated task because not all the components of pedagogical activity are directly revealed during activities. The analysis of higher education and professional activity interaction and methodology of competence research is of high importance and it aims to define spheres of music teacher activity and components of competence (learning/study outcomes).

The recent trend in Europe and Lithuania has been to concentrate music teacher education in higher education, namely at university higher education institutions. The present study focuses on Lithuanian University of Educational Sciences. The duration of initial music teacher education is four years for a Bachelor's degree and two years for a Master's degree. Bachelor's degree curriculum (240 ECTS credits) now include a module of pedagogical studies and teaching practice (60 credits) as well as a module of music study subject (90 credits) (Lietuvos edukologijos universiteto..., 2013). The graduates of the study programme of Music Education are qualified to work as school music teachers of comprehensive schools and non-formal music education. The scope of the Master's degree curriculum is 120 ECTS credits (it includes writing and defence of thesis of 30 credits). Research competence is one of the main aspects of concern in music teacher education on Master's level.

Problem statement. Up to now the main problem faced implementing the change in curriculum has been teacher education (Dèl pedagogu rengimo modelio..., 2017). The current paradigm of music teacher education still has a focus on subject-oriented teacher training (Lasauskiene, 2010). But on the other hand, the experience of educating music teachers at Lithuanian universities has long traditions and is quite original. Another extreme is observed in other countries, when the content of subject teacher training is restricted on utilitarian basis ("a teacher has to know as much as it is necessary for teaching of learners"). Both extremes are not productive under contemporary conditions (Otacıoğlu, 2016; Menezes, 2015). Thus, the attitudes (ideas, expectations) of student music teachers to their professional activity and competences of music teacher are highly 
important (Legette \& McCord, 2015; Georgii-Hemming \& Westvall, 2010). The data on such expectations would allow not only for a better understanding of students' interests, needs and motivations, but also for a critical analysis of the acceptance of the changes entailed by music teacher education.

The aim of the study is to investigate student music teachers' expectations regarding their future professional activity and competences of music teacher.

The methods of research: analysis of scientific sources, document analysis, students' questionnaire survey (open-ended questions), content analysis.

\section{Understanding Music Teachers' Professional Identities}

Research on preservice music teacher occupational identity often highlights two competing identities: performer and teacher (Girdzijauskienè, 2013; Pellegrino, 2009). According to A. Güsewell et al. (2016), a particular challenge to music teachers' identity construction lies in the articulation between the musician and interpreter identity and the music teacher educational identity. Teacher identity as a construct, however, has been used to represent multiple things (Ballantyne et al., 2012).

A teacher-musician is well aware of the study subject, the branch of science and is able to act in the field. Musical practices create musical identities (Green, 2011). However, a musician can be a perfect performer (a singer, a piano player, a conductor) but not a good teacher. The activity of a teacher-musician is successful, when his/her turns for music and educational activities are closely interrelated (Freer, Bennett, 2012). Professional music teacher education should enable students to reflect their professional identity, to combine their identity as an interpreter with their identity as a teacher, and to consider a multiple, evolving identity which is in keeping with the reality and the requirements of the field (Güsewell et al., 2016). According to V. Tavoras (2015) the study subject of music education is very distinctive and distinguished by specific methods of artistic-musical world cognition. Therefore, competences of music teacher acquire specific features both due to specifics of artistic expression and their links with educational activities. They predetermine peculiarities of (self-) development of professional identities.

A teacher-educator is not only a specialist, who is well-aware of the study subject itself, fundamentals and innovations of the study subjects ascribed to the same area of education, but is also able to convey the accumulated knowledge, skills and experience to others (including knowledge of psychology and its application, understanding of professional ethics and compliance of activities with its principles). It emphasises not only awareness of systemic fundamentals of the study subject of music and its integral links with other study subjects but also understanding of its practical relevance, an ability to use the subject of music for (self-) development of learner's knowledge systems and competences. Therefore, deep knowledge of a subject and pedagogical psychological 
theories do not provide a reliable guarantee that the concepts and procedures necessary for the students will be efficiently introduced (Sakadolskiene, 2017). For this reason, it is important not only to train specialists in education but also to actualise the process of becoming a teacher as well as to highlight the relevance of teacher's personal features, which have impact on the quality of his or her professional activities. Content knowledge and pedagogical content knowledge has to be integrated in the process of studies as much as possible (Zühlsdorf, 2016).

A teacher-researcher. Teacher education should embrace not only the subject, subject didactics and general education knowledge but also an aim to conduct research at school. Teacher education should become a research object. Music teacher education is interdisciplinary studies which combine two areas (music and education), therefore research becomes a complex process requiring competence to use artistic expression forms and methods of social sciences research (Banevičiūtė \& Kudinoviené, 2017). The goal of research-based teacher education for future music teachers is to impart reflective teaching which will help the new teachers solve problems with which they may be faced in practice, through autonomous thinking and logical argumentation (Aspfors \& Eklund, 2017). However, although the research-based education has got much publicity and credit, it has been discussed and criticized. According to the critics, too much focus has been on conventional social sciences instead of more emphasis on the qualification of teachers carrying out research in their own working situation.

A teacher-manager. The activity of music teacher goes broad and includes a big number of various functions (Gapšytė \& Bankauskienè, 2016; Lasauskiené, 2010). Music teacher of general education school participates not only in classroom activity but also organises music activities in school community and are heads of non-formal music education circles. A music teacher analyses environment of music and cultural life in school, continuously improves professional knowledge and style of own activity, participates in public cultural life. Managerial skills of a music teacher are related to public, cultural, artistic expression, promotion of arts, organisation of musical activities and participation in them (ability to bring together learners of different needs for joint musical artistic activity, to organise individual and collective music performance: to lead choirs, orchestras, vocal and instrumental ensembles, to train solo performer) and in creative projects.

\section{Methodology}

Applying the method of questionnaire survey, attempts were made to identify the attitude of students towards activities and competences of a music teacher in a comprehensive school. The data were collected using a questionnaire with open-ended questions, which enables students to express own attitudes towards professional activities and competences of a music teacher as well as to self-evaluate own/personal competences acquired during 
the process of education (Creswell et al., 2011). In this article, the results of the qualitative survey, which was conducted in 2017, will be highlighted.

The questionnaire was devised following the scientific study by the author of the article (Lasauskiene, 2010). The questions were as follows: (1) How do you understand the future professional activity of a music teacher?; (2) What specific competences and personal features are required for a music teacher to teach at school?; (3) Are any changes needed in music teacher's activity and music education studies? The answers to the questions would help to better understand possibilities of optimisation of quality of contemporary music teacher education in higher education institutions.

The data were transcribed and analysed qualitatively by using qualitative content analysis (Žydžiūnaite \& Sabaliauskas, 2017). The analysis was aimed at determination of the meaning units (categories, subcategories) in the text.

Participants. In total 140 students, all pre-service music teachers studying in Lithuanian University of Educational Sciences, took part in the research (Table 1). The sample of qualitative research embraced 76 Lithuanian and 64 foreign (Chinese) Bachelor's and Master's degree students. The subsample of Bachelor's degree students consisted of 88 students (60 Lithuanian and 28 Chinese) and that of Master's degree students embraced 52 students (16 Lithuanian and 36 Chinese). One of specific objective related to possible differences between the expectations of Lithuanian and foreign students, preservice music teachers.

Table 1

Research participants $(n=140)$

\begin{tabular}{|c|c|c|c|c|c|}
\hline \multirow{2}{*}{$\begin{array}{l}\text { Study pro- } \\
\text { gramme } \\
2016-2017\end{array}$} & \multirow[t]{2}{*}{ Student group } & \multicolumn{4}{|c|}{ Year of study } \\
\hline & & First year & Second year & Third year & Fourth year \\
\hline \multirow{2}{*}{$\begin{array}{c}\text { Bachelor } \\
(\mathrm{n}=88)\end{array}$} & Lithuanian & 12 & 13 & 17 & 18 \\
\hline & Foreign & 9 & 6 & 8 & 5 \\
\hline \multirow{2}{*}{$\begin{array}{l}\text { Master } \\
(\mathrm{n}=52)\end{array}$} & Lithuanian & 7 & 9 & & \\
\hline & Foreign & 22 & 14 & & \\
\hline \multirow[b]{2}{*}{ Total } & Lithuanian & & & & \\
\hline & Foreign & & & & \\
\hline
\end{tabular}

The research ethics. Participation in the study was voluntary. The general principles of research ethics were observed (Žydžiūnaitė \& Sabaliauskas, 2017). Seeking to ensure confidentiality and de-identification, the research participants were encoded. 


\section{Results and Discussion}

Students approach towards their professional activity and competences. The results of the conducted research are presented following the guiding questions formulated during the research. Although every student music teacher is a unique personality with his/her individual and subjective attitude and way thinking, the analysis revealed several similar aspects in the music teacher's activities and the expression of competences. However, some remarkable differences were identified as well (Table 2).

Table 2

Students approach towards their professional activity and competences

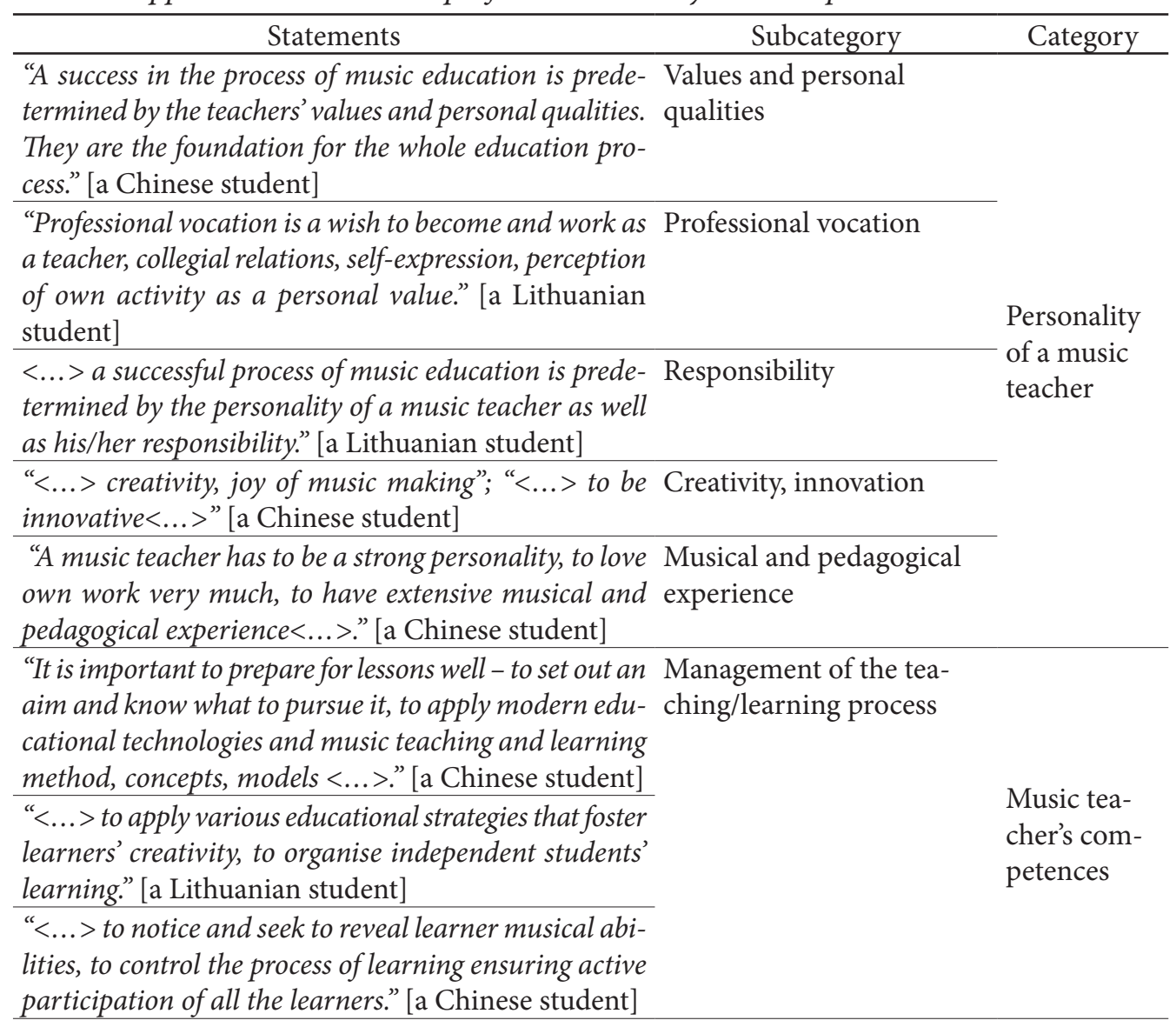




\begin{tabular}{|c|c|c|}
\hline Statements & Subcategory & Category \\
\hline $\begin{array}{l}\text { "It is very important to prepare teaching/learning ma- } \\
\text { terials, which are interesting and attractive to learners, } \\
\text { to adapt a teaching programme to learners' needs, to } \\
\text { integrate the study subject of music into curriculum } \\
\text { through interdisciplinary links." [a Lithuanian student] }\end{array}$ & $\begin{array}{l}\text { Subject content planning } \\
\text { and improvement }\end{array}$ & \multirow{7}{*}{$\begin{array}{l}\text { Music tea- } \\
\text { cher's com- } \\
\text { petences }\end{array}$} \\
\hline $\begin{array}{l}\text { "<...> to select teaching methods that are adequate to } \\
\text { attainment of learning goals. New educational theories } \\
\text { and methods should be applied." [a Lithuanian student] }\end{array}$ & & \\
\hline $\begin{array}{l}\text { "It is very important to know learners, to develop an } \\
\text { individual programme. Good knowledge of learners } \\
\text { would help to appropriately organise musical activities } \\
\text { at school." [a Chinese student] }\end{array}$ & & \\
\hline $\begin{array}{l}<\ldots>\text { only communicating and collaborating with } \\
\text { learners we can achieve goals and learning outcomes, } \\
\text { to properly organise music education." [a Chinese } \\
\text { student] }\end{array}$ & $\begin{array}{l}\text { Communication and coo- } \\
\text { peration }\end{array}$ & \\
\hline $\begin{array}{l}\text { "<...> to create teaching/learning environment that } \\
\text { promotes tolerance and collaboration, where a learner } \\
\text { has opportunities to show initiative and to act indepen- } \\
\text { dently." [a Lithuanian student] }\end{array}$ & $\begin{array}{l}\text { Creation of educational } \\
\text { environments }\end{array}$ & \\
\hline $\begin{array}{l}\text { "<...> to master computer software that is relevant } \\
\text { to music education, to develop learners' information } \\
\text { culture." [a Lithuanian student] }\end{array}$ & $\begin{array}{l}\text { Application of computer } \\
\text { music technologies }\end{array}$ & \\
\hline $\begin{array}{l}<\ldots>\text { it is important to systematically improve own } \\
\text { professional activities." [a Lithuanian student] }\end{array}$ & Professional development & \\
\hline
\end{tabular}

All the student music teachers in the research describe educational activities of a music teacher as broad and multidimensional ones, emphasise the importance of subject-specific, subject content planning and improvement, management of teaching and learning process, learner's cognition and his/her recognition, application of information technologies, creation of educational environments and artistic cultural (event organisation) activities.

The research data show that the students link the competences of a music teacher and their implementation during lessons and extracurricular activities with the teacher as a person. Such a personal contact is the foundation of all his/her competences. Referring to the role of music teacher in a contemporary school, the research participants mainly emphasised the teacher's personality, i.e. his/her values, internal motivation and professional vocation: " $<\ldots>$ a successful process of music education is predetermined by the personality of a music teacher $<\ldots . .>$." [a Lithuanian student].

The Chinese students related the expression of professional competences of the music teacher more to management of the teaching and learning process. The competences of music subject content planning and improvement, communication and cooperation are also regarded as important by foreign students: " $<\ldots$.. only communicating and collab- 
orating with learners we can achieve goals and learning outcomes, to properly organise music education."

The Lithuanian student teachers related the expression of professional competences of the music teacher more to music subject content planning and improvement and teaching relationship (classroom management, management of one-to-one tuition). According to students: "It is very important to prepare teaching/learning materials, which are interesting and attractive to learners, to adapt a teaching programme to learners' needs, to integrate the study subject of music into curriculum through interdisciplinary links". The competences of application of computer music technologies, creation of educational environments, professional development are also regarded as relevant by Lithuanian student music teachers. The students think that a music teacher has to learn and improve lifelong, to seek higher education quality, professional mastery, to change attitudes and style of education.

Lithuanian and foreign students emphasised that musical and artistic activities of a music teacher are very important because " $<\ldots>$ music teacher is the spirit of cultural life at school"; "a person who is active not only musically but also socially". According to the students: "It's a person without whom there wouldn't be any concerts or celebrations at school and in the town." The foreign students in the survey state that in the process of study, more attention should be paid to development and application of musical abilities and competences and concert activities. Participation in musical and artistic activities is important to representatives of all occupations in music. However, it plays a specific role in the spread of professional identity of a music teacher.

It is worth noting that development and application of musical abilities and competences are not ignored in the university; moreover, in the context of the university mission, the academic component (general education studies) is more strongly accentuated (Georgii-Hemming \& Westvall, 2010). On the other hand, developing the 'musician' side of music teachers' identities may ensure the depth of musical experience and content knowledge needed in developing confidence in novice teachers entering the music education profession (Ballantyne et al., 2012).

It is possible to state that student music teachers assign priority to the teacher-creator, approve of collegial relations between the teacher and the learner and acknowledge that the processes of teaching and learning are related processes that create conditions for improvement. This is particularly important in training music teachers. Though reflections of the students revealed that some student music teachers not always manage to abandon a stereotypical attitude to the teacher as an unconditional authority and a source of knowledge (this is more characteristic of the opinion of Chinese students), it is obvious that they feel the importance of pedagogical interaction at school.

The changes necessary in music teacher studies. Music teacher possess specific personal and professional qualities and the majority of them are built up during studies. The research results show that the students relate implementation of changes in studies to a stronger focus of studies on practice and on availability of specialisations (Table 3). 


\section{Table 3}

The changes necessary in music teacher studies

\begin{tabular}{|c|c|}
\hline Statements & Category \\
\hline $\begin{array}{l}\text { "Studies should be more oriented to practice. More practical activity, } \\
\text { individual classes, music courses, musical activities!" [a Lithuanian } \\
\text { student] }\end{array}$ & \multirow{6}{*}{$\begin{array}{l}\text { Focus of studies on } \\
\text { practice }\end{array}$} \\
\hline $\begin{array}{l}\text { "The practical part of music education studies is the most important." } \\
\text { [a Chinese student] }\end{array}$ & \\
\hline $\begin{array}{l}\text { "<...> a music teacher has to acquire practical skills of harmony, piano } \\
\text { and singing." [a Lithuanian student] }\end{array}$ & \\
\hline $\begin{array}{l}\text { "Not all theoretical knowledge can be applied in pedagogical practice } \\
<\ldots . .>\text {." [a Chinese student] }\end{array}$ & \\
\hline $\begin{array}{l}\text { "<...> musical activities (singing, playing an instrument, improvisati- } \\
\text { on and composing as well as participating in concerts, performances) } \\
\text { are the most important. Participation in concerts improves musical } \\
\text { competences." [a Chinese student] }\end{array}$ & \\
\hline $\begin{array}{l}\text { "More psychological training, practice, communication psychology } \\
<\ldots>\text { " [a Lithuanian student] }\end{array}$ & \\
\hline $\begin{array}{l}\text { "Perhaps music teachers of certain areas should be trained (a teacher } \\
\text { of music in comprehension school, a teacher of instrument playing, } \\
\text { a teacher of piano playing, vocal pedagogue?" [a Chinese student] }\end{array}$ & \multirow{2}{*}{$\begin{array}{l}\text { Implementation of speci- } \\
\text { alisations }\end{array}$} \\
\hline $\begin{array}{l}\text { "I think that competences should be related to concrete music teacher } \\
\text { activity area. It would be best if a music teacher could be oriented to } \\
\text { one area." [a Lithuanian student] }\end{array}$ & \\
\hline
\end{tabular}

As stated by the music teacher students, the following changes are necessary in the study area: "more practical activities, individual classes, music courses, musical activities"; "musical activities (singing, playing an instrument, improvisation and composing as well as participating in concerts, performances)"; "more psychological training, practice, communication psychology", because "not all theoretical knowledge can be applied in teaching practice".

On the basis of the conclusions of the qualitative research, institutions that educate music teachers are recommended to take into account the approach and opinion of student music teachers renewing music education study programmes. Further research is recommended to attempt to highlight the change in music teacher's identities in today's educational practice.

\section{Conclusions}

The competences of a music teacher are some of the most significant factors seeking better learning outcomes of school learners' music education. Student music teachers 
describe their professional activities as broad and multidimensional ones but they also emphasise the importance of personal values, implementation of general, subject-specific, professional (didactic) competences and continuous improvement. Participation in musical and artistic activities plays a specific role in the spread of professional identity of a music teacher.

Lithuanian and foreign students expressed diverse evaluations of the activities and competences of music teachers: some are seen in a more favourable light, others are given less favourable assessment. The Lithuanian student music teachers related the expression of professional competences of the music teacher more to music subject content planning and improvement and teaching relationship. The Chinese students linked the expression of professional competences of the music teacher more with management of the teaching and learning process. The research results show that the students relate implementation of changes in studies to a stronger focus of studies on practice and on availability of specialisations.

\section{References}

Abramo, J. M., \& Reynolds, A. (2015). "Pedagogical Creativity" as a framework for music teacher education. Journal of Music Teacher Education, 25(1), 37-51.

Allsup, R. E. (2016). Remixing the Classroom: Toward an Open Philosophy of Music Education. Bloomington: Indiana University Press.

Aspfors, J., \& Eklund, G. (2017). Newly qualified teachers' experiences of the research-based teacher education in Finland. Journal of Education for Teaching. International Research and Pedagogy, 43(4), 400-413.

Ballantyne, J., Kerchner, J. L., \& Aróstegui, J. L. (2012). Developing music teacher identities: an international multi-site study. International Journal of Music Education, 30(3), 211-226.

Banevičiūtè, B., \& Kudinoviené, J. (2017). Development of arts teacher research competence in master studies. Pedagogika, 125(1), 57-67.

Burnard, P., \& Georgii-Hemming, I. (Eds.) (2016). Professional Knowledge in Music Teacher Education. London: Routledge.

Craig, C. (2016). The structure of teacher education. In J. Loughran, M. L. Hamilton (Eds.), International Handbook of Teacher Education. Dordrecht: Springer Press.

Creswell, J. W, Clark, P., \& Vicki, L. (2011). Designing and Conducting Mixed Methods Research ( $2^{\text {nd }}$ edition). Los Angeles: Sage Publications.

Darling-Hammond, L. (2017). Teacher education around the world: what can we learn from international practice? European Journal of Teacher Education. Practice, Theory and Research in Initial Teacher Education. International Perspectives, 40(3), 291-309.

Dèl pedagogu rengimo modelio aprašo patvirtinimo. (2017). Lietuvos Respublikos švietimo ir mokslo ministro įsakymas $2017 \mathrm{~m}$. rugsèjo $14 \mathrm{~d}$. Nr. V-683, Vilnius. Available online at: 
https://www.e-tar.lt/portal/lt/legalActPrint?documentId=685f3fe0992211e78871f4322bb8 $2 \mathrm{f} 27$ (in Lithuanian).

Dél pedagogų rengimo reglamento patvirtinimo pakeitimo. (2012). Lietuvos Respublikos švietimo ir mokslo ministro 2012 m. gruodžio 12 d. įsakymas No. V-1742. Valstybès žinios, Nr. 1497654. Available online at: https://www.e-tar.lt/portal/lt/legalAct/TAR.58B1100C4451 (in Lithuanian).

Dél studijų pakopų aprašo patvirtinimo. (2016). Lietuvos Respublikos švietimo ir mokslo ministro 2016 m. lapkričio 16 d. Nr. V-1012 Vilnius. Available online at: https:/www.e-tar.lt/portal/lt/ legalAct/775fbb90ac0711e6b844f0f29024f5ac (in Lithuanian).

Fang, Y. (2017). Expression of Subject Competence of Future Music Teachers at Lithuanian University of Educational Sciences. Master's Thesis (social sciences, arts pedagogy). Vilnius: Lithuanian University of Educational Sciences.

Freer, P. K., Bennett, D. (2012). Developing Musical and Educational Identities in University Music Students. Music Education Research, 14 (3). Available online at: http://www.tandfonline.com/ doi/abs/10.1080/14613808.2012.712507

Gao, J. (2017). Expression of General and Professional Competencies of Pre-service Teachers of Music at University. Master's Thesis (social sciences, arts pedagogy). Vilnius: Lithuanian University of Educational Sciences.

Gapšyte, G., \& Bankauskienè, N. (2016). Muzikos pedagogo kompetencijų raiška. Socialinis ugdymas, 42(1), 45-59.

Georgii-Hemming, E., \& Westvall, M. (2010). Teaching Music in Our Time. Student Music Teachers' Reflections on Music Education, Teacher Education and Becoming a Teacher. Music Education Research, 12 (3), 353-367.

Girdzijauskiene, R. (2013). Professional Competence of a Music Teacher: Pedagogue Versus Musician. European Perspective on Music Education, 209-223. Helblink: Innsbruck.

Green, L. (2011). Learning, Teaching, and Musical Identity. Voices across Cultures. Indiana University Press.

Güsewell, A., Joliat, F., \& Terrien, P. (2016). Professionalized Music Teacher Education: Swiss and French Students' Expectations. International Journal of Music Education, 1-15.

Holgersen, S. E., \& Burnard, P. (2016). Different types of knowledges forming professionalism: a vision of post-millennial music teacher education. Professional Knowledge in Music Teacher Education, 1, 189.

Lasauskienè, J. (2010). Muzikos mokytojo veikla ir kompetencijos. Vilnius: VPU leidykla.

Legette, R. M., McCord, D. H. (2015). Pre-service music teachers perceptions of teaching and teacher training. Contributions to Music Education, 40(1) 163-176.

Lietuvos edukologijos universiteto studiju programu sandara. (2013). Patvirtinta LEU Senato 2013 m. gegužès 22 d. nutarimu Nr. 220. Prieiga per internetą: https://leu.lt/lt/struktura/ senatas/senato nutarimai.html (in Lithuanian).

Menezes, M. (2015). Training music teachers for the real world: connecting theory and practice. Problems in Music Pedagogy, 14(1), 7-17. 
Otacioğlu, S. G. (2016). Comparison of the education program of institutions raising music teachers in Turkey and those of art universities that raise music teachers in an EU member country. International Journal of Social Sciences and Education Research, 2(3), 1107-1117.

Pellegrino, K. (2009). Connections between performer and teacher identities in music teachers: setting an agenda for research. Journal of Music Teacher Education, 19(1), 39-55.

Sakadolskienè, E. (2017). Ne vien žinios ir gebejjimai: transformacijos per mokytojo socializaciją ir tapatybès ugdymą. Acta Paedagogica Vilnensia, 38, 42-57.

Tavoras, V. (2015). Meninè individualybè ir jos raiškos plètojimo muzikine veikla galimybès universitete. Vilnius: Lietuvos edukologijos universitetas.

Zühlsdorf, F. (2016). Teacher education at university: how to teach content knowledge and pedagogical content knowledge in an integrated way. In Bringing Teacher Education Forward: National and International Perspectives. Programme and Abstracts. Oslo: University of Oslo. Zuzevičiūtè, V., \& Bukantaitė, D. (2012). Muzikinio ugdymo realijos ir muzikos ugdytojų rengimas. Kaunas: Vytauto Didžiojo universitetas.

Žydžiūnaitè, V., \& Sabaliauskas, S. (2017). Kokybiniai tyrimai:principai ir metodai. Vilnius: Vaga.

\title{
Muzikos mokytojo veikla ir kompetencijos: Lietuvos ir užsienio studentų lūkesčiai
}

\author{
Jolanta Lasauskienè
}

Lietuvos edukologijos universitetas, Ugdymo mokslų fakultetas, Muzikos katedra, Studentų g. 39, 08106 Vilnius, jolanta.lasauskiene@leu.lt

\section{Santrauka}

Straipsnyje analizuojamas studentų, būsimųjų muzikos mokytojų, požiūris ị profesinę veiklą ir bendrojo ugdymo mokyklos muzikos moky tojo kompetencijas. Tyrime dalyvavo 76 lietuviai ir 64 užsienio studentai (kinai), studijuojantys Lietuvos edukologijos universitete, Muzikos katedroje.

Šiame straipsnyje išryškinami kokybinio tyrimo, atlikto 2017 m., rezultatai. Duomenys rinkti taikant apklausos raštu (naudojant atvirojo tipo klausimyną) metodą.

Tyrime dalyvavę studentai - būsimieji muzikos mokytojai - turi savitą požiūrị i̇ muzikos mokytojo veiklą ir kompetencijas. Edukacinę muzikos mokytojo veiklą studentai apibūdina kaip plačią, daugialypę ir akcentuoja mokytojo vertybių, bendrųjų, dalykinių, profesinių (didaktinių) kompetencijų bei meninės muzikinės veiklos svarbą. Kalbėdami apie muzikos mokytojo vaidmenị šiandienejje mokykloje, studentai daugiausia dèmesio kreipe į mokytojo asmenybę, t. y. jo vertybes, asmenines savybes (profesinị pašaukimą, atsakomybę, savarankiškumą, kūrybiškumą), vidinę motyvaciją, pedagoginès sąveikos mokykloje svarbą. 
Lietuvių studentai muzikos mokytojo profesinių kompetencijų raišką daugiau sieja su dalyko turinio planavimu ir tobulinimu (parengti mokiniams įdomią ir patrauklią mokymosi medžiagą, atrinkti mokymo(si) metodus, tinkamus mokymo(si) tikslams pasiekti). Svarbiomis muzikos mokytojo kompetencijomis jie nurodo kompiuterinių muzikos technologijų naudojimo, ugdymo(si) aplinkų kūrimo, profesinio tobulejjimo kompetencijas. Studentai mano, kad muzikos mokytojui svarbu nuolat mokytis ir tobulèti, siekti aukštesnès ugdymo kokybès, profesinio meistriškumo.

Užsienio studentai (kinai) palankiau vertina muzikos mokytojo mokymo(si) proceso valdymo kompetencijas (prieinamai ir suprantamai mokiniui perteikti ugdymui(si) reikalingą informaciją, naudoti įvairias ugdymo strategijas, plètojančias mokinių kūrybiškumą, kritinị mąstymą). Svarbiomis muzikos mokytojo kompetencijomis jie nurodo bendravimo ir bendradarbiavimo, mokinio pažinimo ir jo pripažinimo kompetencijas. Pokyčių igyvendinimas muzikos pedagogikos studijose siejamas su studijų orientacijos ị praktiką stiprinimu ir specializacijų sukūrimu.

Esminiai žodžiai: muzikos mokytoju ugdymas, studentas muzikos mokytojas, kompetencijos, studentų lūkesčiai. 